\title{
COMPERITIVE PARAMETRIC STUDY OF BRICK PANEL FOR LINEAR STATIC AND MODAL ANALYSIS
}

\author{
Ashish Padhshala ${ }^{1}$, Rudra Upadhyay ${ }^{2}$ \\ ${ }^{1}$ Student of Civil Department, Gandhinagar Institute of Technology, Gandhinagar, India \\ ${ }^{2}$ Student of Civil Department, Gandhinagar Institute of Technology, Gandhinagar, India
}

\begin{abstract}
Brick walls are part of our structure since late $79^{\text {th }}$ century B.C. Bricks is ideal material for construction due to its economical and it contains high compressive strength. Thus it is used in almost all structural construction in India. In this work $3 D$ Finite element models of brick panels were developed using Sap2000 software. Parametric studies have been done for in plane loading. Linear Static and dynamic analysis was carried out. Main two types of bonds English bond and Flemish bond are considered here. Comparative study has been carried by developing load/deflection curve and by Modal analysis
\end{abstract}

Keywords—English bond, Flemish Bond, Modal Analysis

\section{INTRODUCTION}

Bricks have been part of our life since ages. The oldest discovered bricks, originally made from shaped mud and dating before $7900 \mathrm{BC}$, were found at Tell Aswad, in the upper Tigris region and in southeast Anatolia close to Diyarbakir ${ }^{[8]}$. At Present, brick is most important undeniable function of structure. It is widely used in foundation to load bearing walls as structure component. In over $90 \%$ structures in India brick is main structural component. Easy availability of the material, economical in construction, high load bearing capacity and high compressive strength are reasons of its wide use among all type of structures. There are various types of brick bonds but most commonly used brick bonds are English bond and Flemish bond. Brick wall has a very good compressive strength. It can take high loads from the upper elements and distribute it to the soil. However, in present day practice of building design, buildings are designed as framed structures while effect of infill masonry walls is ignored and considered as non-structural elements. Brick walls are highly vulnerable against seismic loading. To study this vulnerability, effect of seismic loading has been studies by developing deflection curve, studying variance in frequency by change in mode shape.

\section{METHODOLOGY}

F.E.M. based software Sap2000 have been used for the modelling of the brick panel. Effect of the essential parameter like bond type and height to width ratio were studied by applying lateral in-plane load, which applied on concrete beam kept at top of the wall. Deflections of opposite end were measurement as check and modal analysis has been also carried out.

\section{MATERIAL MODELLING}

Following material properties were used for analysis

Table1. Material Characteristics ${ }^{[3][4]}$

\begin{tabular}{|l|l|}
\hline Term & Value \\
\hline Unit weight of Brick & $19.20 \mathrm{KN} / \mathrm{m}^{3}$ \\
\hline Elastic Modules Of Brick & $2640 \mathrm{MPa}$ \\
\hline Poison's Ratio of Brick & 0.16 \\
\hline Unit weight of mortar & $14.76 \mathrm{KN} / \mathrm{m}^{3}$ \\
\hline Elastic Modules of mortar & $545 \mathrm{MPa}$ \\
\hline Poisons Ratio of mortar & 0.15 \\
\hline Grade Of Concrete & $\mathrm{M} 20$ \\
\hline $\begin{array}{l}\text { Unit Weight of Reinforced } \\
\text { Concrete }\end{array}$ & $25 \mathrm{KN} / \mathrm{m}^{3}$ \\
\hline $\begin{array}{l}\text { Modules of elasticity of } \\
\text { Reinforced concrete }\end{array}$ & $22360.7 \mathrm{Mpa}$ \\
\hline Poison's Ratio & 0.15 \\
\hline
\end{tabular}

\section{SCOPE OF THE WORK}

To determine effect of various brick wall properties, here parametric study has been done. A lateral load is varied from $100 \mathrm{KN}$ to $400 \mathrm{KN}$ were applied on the top. To study the shear and bending behaviour of brick panel here height/width ratio varied 0.25 to 2 . Based on output results load-deflection graph is prepared. First three predominant mode shapes are studied 


\section{RESULTS AND DISCUSSION}

\subsection{Bond Effect}

To find out effect of the bond on brick panels during lateral loading, English bond and Flemish bond brick panel were loaded up to $200 \mathrm{kN}$, by various H/W ratios. In Fig-1 loaddeflection curves were plotted for above cases. From Fig-1 it can be observed that for all $\mathrm{H} / \mathrm{W}$ ratios, slope of loaddefalcation curve for Flemish bond has higher slope. Thus these indicate that lateral stiffness of brick Flemish brick panel is higher than the brick panel with English bond.

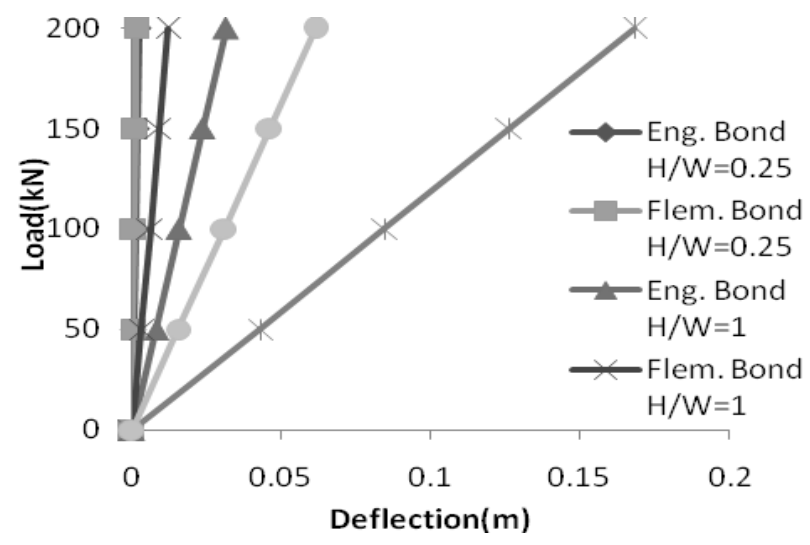

Fig 1 Effect of Different Bonds under Various Loading

In general it is expected that English bond performs better than Flemish bond. This result may be due to assumption of perfect bond between brick and mortar.

\subsection{Modal Analysis}

The 3D F.E.M models are used to access the modal behaviour of English and Flemish bond masonry panels. Frequency and time periods of first three mode shapes are mentioned in table 2. The first and second modes are translational in transversal and longitude directions. Third mode shape shows the tortional mode. Fig 2, 3 and 4 shows the three mode shapes respectively of both English and Flemish bond.

Table2. Time period and frequency of English bond and Flemish bond brick panel for 3 mode shapes

\begin{tabular}{|l|l|l|l|l|}
\hline $\begin{array}{l}\text { Mode } \\
\text { Shape }\end{array}$ & \multicolumn{2}{|l|}{ English Bond } & \multicolumn{2}{l|}{ Flemish Bond } \\
\hline & $\begin{array}{l}\text { Time } \\
\text { Period }(\text { Sec })\end{array}$ & $\begin{array}{l}\text { Frequency } \\
(\mathrm{Hz})\end{array}$ & $\begin{array}{l}\text { Time } \\
\text { Period }(\text { Sec })\end{array}$ & $\begin{array}{l}\text { Frequency } \\
(\text { Hz) }\end{array}$ \\
\hline $\begin{array}{l}\text { Mode } \\
\text { Shape } \\
1\end{array}$ & 0.96766 & 1.03343 & 0.81545 & 1.22631 \\
\hline $\begin{array}{l}\text { Mode } \\
\text { Shape } \\
2\end{array}$ & 0.18966 & 5.27269 & 0.15933 & 6.27625 \\
\hline
\end{tabular}

\begin{tabular}{|l|l|l|l|l|}
\hline $\begin{array}{l}\text { Mode } \\
\text { Shape } \\
3\end{array}$ & 0.11781 & 8.48798 & 0.1218 & 8.20465 \\
\hline
\end{tabular}
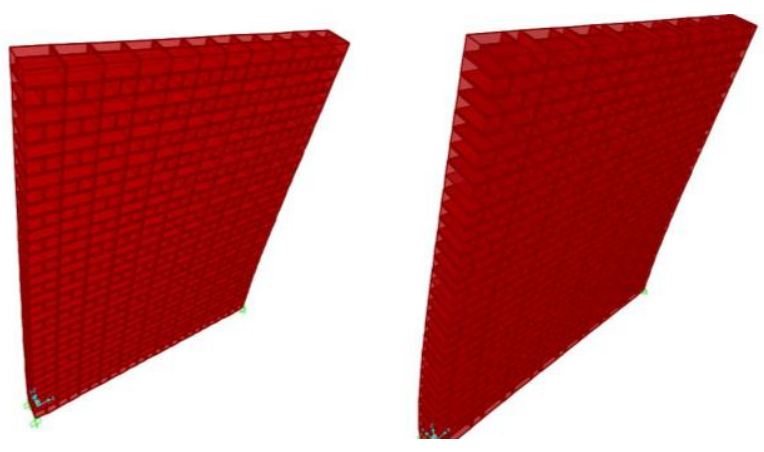

Fig2. First mode shape of English and Flemish Brick panel
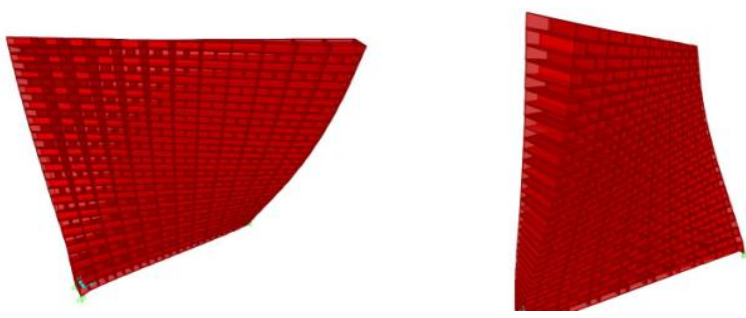

Fig3. Second mode shape of English and Flemish Brick panel
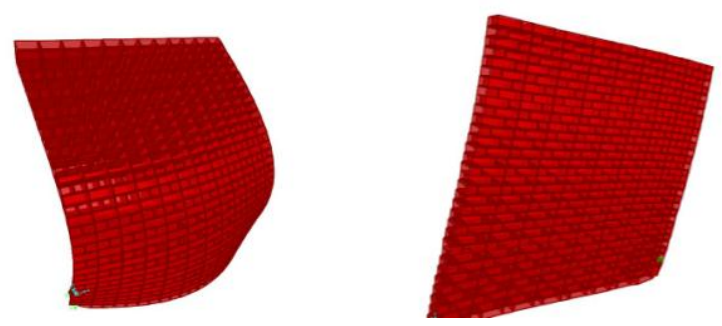

Fig4. Third mode shape of English and Flemish Brick panel

The mode shapes demonstrate that brick panels moderate deformations due to reasonable tortional and transverse stiffness. English bond have slightly high transverse stiffness whereas Flemish bond has slightly high tortional stiffness.

\section{CONCLUSIONS}

Parametric study has been done to determine effect of type of brick bond and modal analysis has been studied to understand mode shape behaviour of bonds. To do this F.E.M. based models were developed using SAP2000. Flemish bond found to be stronger than English Bond for lateral loading. For height/width ratio more than 1 rate of deflection were increased due to bending deformation. Whereas in modal analysis study English bond have slightly high transverse stiffness and Flemish bond has slightly high tortional stiffness compare to each other. 


\section{REFERENCES}

[1] National building code 2005, Bureau of Indian Standards, 1970

[2] G.Sarangapani, B.V.Venkatarama Reddy and K. S. Jagadish (2002) "Structural characteristics of bricks, mortars and masonry", Journal of Structural Engineering Vol. 29. No. 2

[3] I.S. 2250-1981, "Code for practice for preparation and use of masonry mortar", Bureau of Indian Standards, 1962

[4] I.S. 2212-1991, "Brick Works-Code of Practice", Bureau of Indian Standards, 1962

[5] Hemant B. Kaushik ${ }^{1}$; Durgesh C. Rai ${ }^{2}$; and Sudhir K. Jain, M.ASCE ${ }^{3}$ "Stress-Strain Characteristics of Clay Brick Masonry under Uniaxial Compression", 10.106/(ASCE)0899-1561(2007)19:9(728)

[6] Pankaj Aggarwal, S.K. Thakkar, "Comparative Study of Brick Masonry House Under Quasi Static and Dynamic Loading”, ISET Journal of Earthquake Technology, Paper No. 414, Vol. 38, Nov 2-4, June-Dec 2001, pp. 103-122

[7] Momin Mohmedakil, P.G.Patel, "Seismic Assessment of RC Frame Masonry Infill with ALC Block" EISSN2249-8974

[8] History of brick making, Encyclopedia Britannica. 